\title{
ETHNOPEDAGOGICAL POTENTIAL OF THE CHUVASH CULTURE: FROM ANCIENT TURKIC RUNES TO MODERN LITERATURE
}

\author{
Elena Chekushkina ${ }^{1}$, Ekaterina Yakimova ${ }^{2}$, Natalia Nikolaeva $^{3}$, Raisa Vasileva ${ }^{4}$ \\ Eduard Fomin $^{5 *}$ \\ ${ }^{1}$ Assoc. Prof. Dr., Chuvash State University, RUSSIA, enarpi@mail.ru \\ ${ }^{2}$ Assoc. Prof. Dr., Chuvash State University, RUSSIA, katya-af@yandex.ru \\ ${ }^{3}$ Senior lector, Chuvash State University, RUSSIA, nicknata75@inbox.ru \\ ${ }^{4}$ Assoc. Prof. Dr., Chuvash State Institute of Culture and Arts, RUSSIA, chgiki.gsed@mail.ru \\ ${ }^{5}$ Assoc. Prof. Dr., Chuvash State Institute of Culture and Arts, RUSSIA, yeresen@yandex.ru \\ ${ }^{*}$ Corresponding Author
}

\begin{abstract}
This work is devoted to the study of the educational potential of the Chuvash traditional written culture. The main aspect on which the conclusions of the study are based is ethnopedagogical one. The authors study the cult images of the ancient Turkic era in their application to the verbal culture of the Chuvash people and the possibility of using archetypal representations in pedagogical practice. Samples of Turkic peoples' oral folk literature, mainly of the Chuvashes, as well as texts written in the Orkhon-Yenisei runic tradition were used as the research material. The authors turn to methods of comparative analysis of the studied material. The worship of the sky and the female deity is quite well known in ancient Turkic culture. Traces of respect for them are found even in runic monuments. Their direct analogs are found in Chuvash legends, fairy tales and songs. The mention of the goddess Ama 'mother' is most often found in prayers. Her image of the Chuvash was also compared to the image of fire, naming the goddess Vut ama 'Fire mother'. The Chuvash people also preserved the veneration of land and water, which is observed in mythology, religious rites and cultic literature. These images are one of the central elements in the value picture of the Chuvash people's world. They are used in the system of preschool and primary education for teaching and educational purposes. From this work authors' point of view, mythological representations are essentially an ancient layer that unites the Chuvash with other Turks and at the same time gives an original sound to modern Chuvash culture. The transformation of the ancient Turkic worldview into artistic images should be considered as a deep specificity that emphasizes the unique features of the Chuvash ethnos. Thus, especially revered phenomena among the ancient Turks are the sky and the female deity. Their veneration was clothed in expressive forms. With the passage of time, poetic images and traditions were woven into religious rituals and oral literature of the Chuvash, and then passed into the artistic elements of modern Chuvash literature.
\end{abstract}

Keywords: ethnopedagogy, folklore, traditional upbringing, Chuvash ethnos, Turkic runes, Chuvash ceremonies and rituals.

\section{INTRODUCTION}

In the modern science, the problem of studying the prehistory of Chuvash literature, as well as the formation of poetic traditions and genres in the culture of the Volga region peoples, is of interest to many scientists (Borisova, 2012), (Rodionov, 2006), (Sofronova, 2004), (Chekushkina, 2004), (Chekushkina, 2016), (Yakimova, 2016), (Chekushkina, Yakimova, Sofronova, Nikolaeva, Rodionov, 2020). However, the ancient Turkic era, when the Turkic peoples lived in a single cultural space, still requires new versatile research. 
The problem of the Chuvash written culture ethnopedagogical potential has never become an object of scientific research. As a rule, ethnopedagogy refers to folklore material. Meanwhile, the presence of folklore traditions in literary creativity allows us to see ethnopedagogical principles in its composition.

\section{METHODOLOGY}

The aim of our work is to study the ethnopedagogical properties of the most ancient Turkic texts and samples of Chuvash cult literature in conjunction with literary works.

Examples from Turkic peoples' folklore and Chuvash literature served as research material. The authors also refer to runic writing samples. The conclusions of the work are based on the result of a comparative approach to the material.

\section{OPINIONS AND DISCUSSION}

The chronological boundaries of the ancient Turkic time cover the period from about the 6th to the first quarter of the $10^{\text {th }}$ century AD. As you know, the ancestors of the Chuvash - the ancient Bulgars - at that time had already gone through their rather turbulent history and already lived first in the region of the North Caucasus, and later, having moved to the North, settled in the vicinity of the Volga River.

The most ancient written culture examples of the ancient Turkic period are the Orkhon and Yenisei inscriptions. Their deep interconnections still need detailed study, however, they reveal common poetic traditions that apparently existed in the pre-Turkic time, and therefore they can be traced among many Turkic-speaking peoples, including the Chuvash. We agree with the opinion of the researcher of ancient Turkic texts I. V. Stebleva, who states: "The ancient Turkic writings ... reflected the existence of a single literary tradition, which has a natural evolution, characterized by the presence of its own artistic style, elements of which can be easily traced in the later legends of the Turkic peoples" (Stebleva, 1965, p. 14). According to the Chuvash researcher V. G. Rodionov, "...the Turkic-speaking peoples, who, by the will of history, could not inherit the verse traditions of the classical Turkic-speaking literature, will turn primarily to the traditions of oral, not written literature" (Rodionov, 2006, p. 3).

The Chuvash are one of the Turkic-speaking peoples who turned not directly to classical Turkic literature, but to the oral traditions of the Turks. These traditions, as a rule, are found in the written culture of the ancient Turkic people. For example, the motive of venerating the sky as a deity runs like a golden thread through the Orkhon inscriptions. For example, let us turn to the monument in honor of Tonyukuk, where we read the following lines: "The sky, perhaps, said so: I gave (you) a khan, you, leaving your khan, obeyed others. Because of this submission, heaven - one might think - struck (killed) (you). The Turkic people weakened and came down to nothing" (Malov, 1951, p. 64). The same reasoning is found in the Big inscription in honor of Kul-tegin: "The sky, which, so that the name and glory of the Turkic people would not disappear, raised my father-kagan and my mother-katun. The sky, giving (khans) states, has put me, presumably as a kagan, so that the name and glory of the Turkic people would not disappear" (Malov, 1951, p. 39). The emphasis on the celestial origin of the Turkic kagans is also found in the Small Inscription, based on this, one must think that the sky, according to the ideas of the ancient Turks, acted as a divine power.

Giving the sky divine functions is characteristic not only of the Orkhon inscriptions, we find such an artistic solution in the Fortune-telling book, which dates back to the VIII-IX centuries AD. For example, in section $\mathrm{XVII}$ it is told about a horse that was saved from death by the grace of heaven: "The riding horse was completely emaciated and exhausted. By the might of the sky on the mountain on the southern side, it saw mountain streams and water, and in the thicket it saw green grass. It quickly went and, after drinking water and eating grass, got rid of death" (Malov, 1951, p. 86). The worship of the sky existed even before our era among the Hunnu tribe, as reported by the orientalist-sinologist N. Ya. Bichurin (Bichurin, 1950, p. 49). In the Chuvash oral literature, there is also giving the sky a divine image. By its origin, tură - Turkic tanrï, tengiri, taniri, tanara, tengir, originally meant the sky; this meaning is still preserved in the Chuvash folk art: Uyartat'-i pĕr tură. / Ah, turăsaăm, tură, / İră kuras pulsassăn / Šănkăr uyar pul, tură. 'Does the weather clear up on the Torah, / Ah, Torah, my Torah, / If there is to be happiness, / Tora, be serene and sunny, Tora', N. I. Ashmarin states, reflecting on the original meaning of tură 'god' (Ashmarin, 1982, p.18-19).

Indeed, the ancestors of the Chuvash thought a lot about the relationship between people and the spiritual sphere, calling the latter nothing other than heaven. So, one Chuvash legend tells why heaven and earth became distant for each other. According to the legend, at the dawn of mankind, the sky hung very close to the earth. People easily reached the heavens and healed their bodily sores and mental wounds. Such a close location of heaven above earth meant that initially the God and people were spiritually close to each other, so the God could easily hear them and could give various benefits they needed. So, according to the 
ideas of Chuvash ancestors, in ancient times, the God and the sky were one. However, one slovenly Chuvash woman offended the God by sticking a wad of dirty diapers of her child into the sky. After this outrageous act, it went up and since then had become unattainable to mere mortals.

In Orkhon inscriptions, along with the veneration of the image of the sky, the name of the goddess Umay is often mentioned: "the sky, (goddess) Umay, the sacred homeland (earth-water) - here they are, I think, gave (us) the victory" (Malov, 1951, p. 68). This is a female deity, and her name is mentioned in monuments almost on a par with the God. The sky and the goddess Umay in the view of the ancestors of the Turks were the patrons of victories in war, and the goddess Umay also performed a punishing function.

As many researchers note, the cult of the Great female deity has come a long historical path. So, in the first centuries of our era, the image of the goddess Orsilohi is known in history, who was depicted with sprouting hands and together with two forthcoming winged griffins. In the Black Sea steppes, the formidable goddess Virgo appeared, to whom human sacrifices were also brought.

The veneration of the goddess Umay image also goes back to the cult of the Great female deity. Most often, her power was associated with military actions, but she was also a symbol of fertility. Later, only a part of the divine functions remained in the image of this goddess. So, it is known that in the nineteenth - early twentieth century, she was the keeper of small children and her image participated in rituals associated with the birth of a child into the world and its early childhood (Grach, 1980, p. 67-69). This image is found among the Shors and Sagays. Their word Umay or Ïmay refers to the soul of a child from the moment of its birth to the age of three (Potapov, 1973, p. 271). It is also known that Umay is worshiped by the Turkic-speaking peoples of the Sayan-Altai highlands.

The image of the Great goddess is also present in Chuvash mythology. The name of the goddess is Ama. The oldest mother is what the researcher of the old Chuvash faith V. K. Magnitsky calls her. It was to her that the Chuvash people turned in prayer: Ey, pětěm těnčene śuratnă Ama! Sanran pulni purte usăllă, purte avan, śavănpa epir sana yalanax tivěślipe čükletpĕr. 'Oh, Ama, who gave birth to all the world! What you have created is all useful and good, so we always thank you with dignity and make prayers' (Ashmarin, 1982, p. 20).

This ancient Chuvash prayer was recorded by the Turkologist N. I. Ashmarin. According to the Chuvash, Ama is the progenitor of all living things and the Chuvash worshiped her image since ancient times. Later, the image of Ama was also identified with the image of fire - Vut ama 'Mother-fire'.

L. Potapov states that many modern Turkic peoples of Siberia and Central Asia have this deity. For example, among the Khakas, the shaman turned to Umay, invoking fire (Potapov, 1973, p. 280). The Chuvash also treated fire with care and often turned to it in prayers.

The female deity cult of the Chuvash people was greatly influenced by the penetration of Christian ideas into the Chuvash environment. However, as N. I. Ashmarin notes, "Christian ideas could merge with the old, popular ones". This feature is emphasized by V. K. Magnitsky. He writes that the Chuvash people did not forget their pagan gods and treated Christian shrines in a purely shamanic way, and often translated Christian concepts that were foreign to them into their native language with words borrowed from their own mythology (Magnitsky, 1881, p. 218-219).

So, the existence of the deity Ama image among the Chuvash people in ancient times, later helped them quickly strengthen their veneration of the image of the mother of God (Tură amăšĕ), an image that later became firmly established in prayers.

In runic monuments, in addition to the cult of the sky and the goddess Umay, there is another cult-the worship of the deity Yuduğ yer sub (literally Holy land-water. - E. Ch.) or the cult of the sacred land-water. The fact that the antiquity of this cult is confirmed by Chinese Chronicles, is noted by the sinologist N. Ya. Bichurin. These Chronicles report on the land worship of the Hunnu peoples in the last centuries BC. This cult also existed among the peoples of wuhuan (Bichurin, 1950, p. 49,65). The sacred land-water (Yuduğ yer sub) is also mentioned in ancient Turkic runic texts. Thus, the Yenisei inscriptions emphasize the hero's regret for the rapid separation from the sacred land-water, i. e., from the Motherland. For example: "You ... my ale, you, my land [and] water, [I did not enjoy]" (Stebleva, 1965, p. 140). And in Orkhon inscriptions, the sacred land-water often acts as a benefactor. For example: "(But) above is the Sky of the Turks and the sacred Land and Water of the Turks (i. e. Homeland) so they said: let the Turkic people not perish, saying, let them be a people", - so they said (Malov, 1951, p. 37).

The worship of yer-su spirits is one of the most ancient cults of mankind. It also applies to the religious system of the ancient Turks, and its roots go back to the primitive era of human existence. According to the 
Kazakh poet-thinker O. Suleimenov, the worship of yer-su was still common among the Sumerian people, which eventually penetrated into the Turkic environment (Suleimenov, 1975, p. 256-261).

The presence of this cult was also observed among the modern Turkic-speaking peoples of the Sayan-Altai highlands. In ancient times, they had the goddess Yer-su, who was the patroness of earth and water, and the cult of yer-su was associated with the worship of mountains. Among the Chuvash people, this cult has also been preserved, and the worship of land and water is observed in mythology, various religious rites, the cult literature of their ancestors, and fiction.

The Hungarian researcher D. Mészáros also writes that the Chuvash in the philosophical understanding of the earth have remnants of shamanism dating back to ancient Turkic times. The land, according to the ideas of the Chuvashes, was in the form of a breastfeeding mother. The Chuvash said: Pire śĕr kăkri tărantarat. 'We are fed by the breast of the earth' (Mészáros, 2000, p. 55).

The tribes of the Chuvash ancestors have been farmers since ancient times, and therefore their sacrifices in the past were mostly associated with the earth - the mother goddess, and mother earth was also most often mentioned in prayers. Many researchers note that in many Chuvash rites and rituals associated with the earth, there is a reverent attitude towards the nurse-earth as a goddess-mother. For example, the holidays śinśe, akatuy 'the wedding of sowing', the ceremonies śumăr čük 'praying to the rain', śér vărlani 'the theft of land' were directly related to imparting human qualities to the earth. So, during the śinśe holiday, it was impossible to disturb the earth by performing any work, since it was believed that the earth was pregnant during this period. Or during the akatuy holiday, according to the beliefs of the Chuvash, a wedding took place - the marriage of the land with the plow, and during the śumăr čük mother earth received the necessary strength - water. As a result of these rituals, the land became pregnant and gave birth to grain fields. And with a constant crop failure, another ritual was performed, called śĕr vărlani, its main meaning was to transfer the fertile qualities of a foreign field to the lands of own village by "stealing" an insignificant part of the land (Denisov, 1959 p. 142-145). This rite found its artistic embodiment in the socio-historical novel by F. Uyar "Tanata" ("Snares"), in which according to the plot the inhabitants of one village, due to a systematic crop failure, "steal" the land of a neighboring village, like a bride, and "marry" the orphan Ukhtivan. Subsequently, Ukhtivan, "married to stolen land", had no right to start a family.

In the life of the Chuvash ancestors, water, like land, was also considered sacred. For example, when performing the rite šï čükĕ 'prayer to the water' or külĕ čükĕ 'prayer to the lake', they read prayers to the water. As D. Mészáros notes, the Chuvash people annually offered a redemptive sacrifice to the "father of water" and the "mother of water", so that they would not frighten people near reservoirs when bathing or crossing the water, or when watering, they would not send diseases to animals (Mészáros, 2000, p. 68). So, the classic poem of the Chuvash poet K. Ivanov "Narspi" ends with the story that during the years of drought, the villagers of Silbi pour water on the grave of the unfortunate heroine Narpsi. This action is performed with the belief that her restless spirit can come out through the cracks in the arid earth and can frighten the rain clouds. And so that the soul of the unfortunate girl does not bring drought to the villagers, this rite is performed.

\section{CONCLUSION}

Thus, the sky and the female deity, the sacred earth-water, originating in the ancient Turkic culture and reflected in runic monuments, were revered for many centuries by the ancestors of the Turkic peoples. Mythological ideas are an ancient layer that unites the Chuvash with other Turks and at the same time gives the modern Chuvash culture an original sound. The transformation of the ancient Turkic worldview into artistic images should be considered as a deep specificity, emphasizing the unique features of the Chuvash ethnos. Over time, the veneration of the sky and the female deity was clothed in expressive forms, poetic images and traditions were woven into the religious rites and oral literature of the Chuvash, and then passed into the artistic elements of modern Chuvash literature.

The possibilities of using the ideas outlined in runic records, samples of oral folk literature and literary works intertextually connected with each other are endless in ethnopedagogical terms. Until recently, in the Chuvash environment, folklore fully served pedagogical and educational tasks, where solving riddles served as lessons in mathematics and logic, retelling of myths, legends and fairy tales represented lessons in literature and history. Nowadays, they can be used in childhood as role models in environmental education; for adults, they can serve as a key to understanding their ethnicity, philosophical reflections on the life essence. 


\section{REFERENCE LIST}

Ashmarin, N. I. (1982). Introduction to the course of Chuvash folk literature. Chuvash folklore. The specificity of the genres.

Bichurin, N. Ya. (1950). Collection of information about the peoples who lived in Central Asia in ancient times, vol. 1.

Borisova, L. V. (2012). The concept sphere "family" in the Chuvash language picture of the world. Bulletin of the Chuvash University, No 4.

Grach, A. D. (1980). Ancient nomads in Central Asia.

Denisov, P. V. (1959). Religious beliefs of the Chuvash: Historical and ethnographic essays.

Magnickiy, V. K. (1881). Materials for the explanation of the old Chuvash faith.

Malov, S. E. (1951). Monuments of ancient Turkic writing.

Mészáros, Dy. (2000). Monuments of the old Chuvash faith, vol. 1.

Potapov, L. P. (1972-1973). Umay - the deity of the ancient Turks in the light of ethnographic data. Turkological collection.

Rodionov, V. G. (2006). Ethnicity. Culture. Word.

Sofronova, I. V. (2004). Traditions of Eastern poetry in the Chuvash lyrics in the 20-30-s of the twentieth century.

Stebleva, I. V. (1965). Poetry of the Turks in the VI-VIII centuries AD.

Suleymenov, O. (1975). Az and I: a well-meaning reader's book.

Chekushkina, E. P. (2004). General Turkic artistic traditions in Chuvash literature.

Chekushkina, E. P. (2016). The image of Ulyp is an echo of the ancient Turkic world. Chuvash language and literature: theory and methodology.

Chekushkina E.P., Yakimova E.R., Sofronova I.V., Nikolaeva N.V., \& Rodionov V.G. (2020). The concept of the heavenly bodies in the Chuvash literature and in the poem "NARSPI" by K. Ivanov. International E-Journal of Advances in Social Sciences, vol. 6, issue 16.

Yakimova, E. R. (2016). The genre of historical tragedy in the Volga region dramaturgy. Philological sciences. Questions of theory and practice. 